\title{
Hal E. Broxmeyer PhD: Experimental hematologist and umbilical cord blood cell transplant pioneer (27 November, 1944-8 December, 2021)
}

\author{
Mariusz Ratajczak ${ }^{1}$, Éliane Gluckman ${ }^{2}$ and Robert Peter Gale $\mathbb{D i D}^{3 \times}$ \\ (c) The Author(s), under exclusive licence to Springer Nature Limited 2022
}

Bone Marrow Transplantation (2022) 57:691-692; https://doi.org/10.1038/s41409-022-01576-y

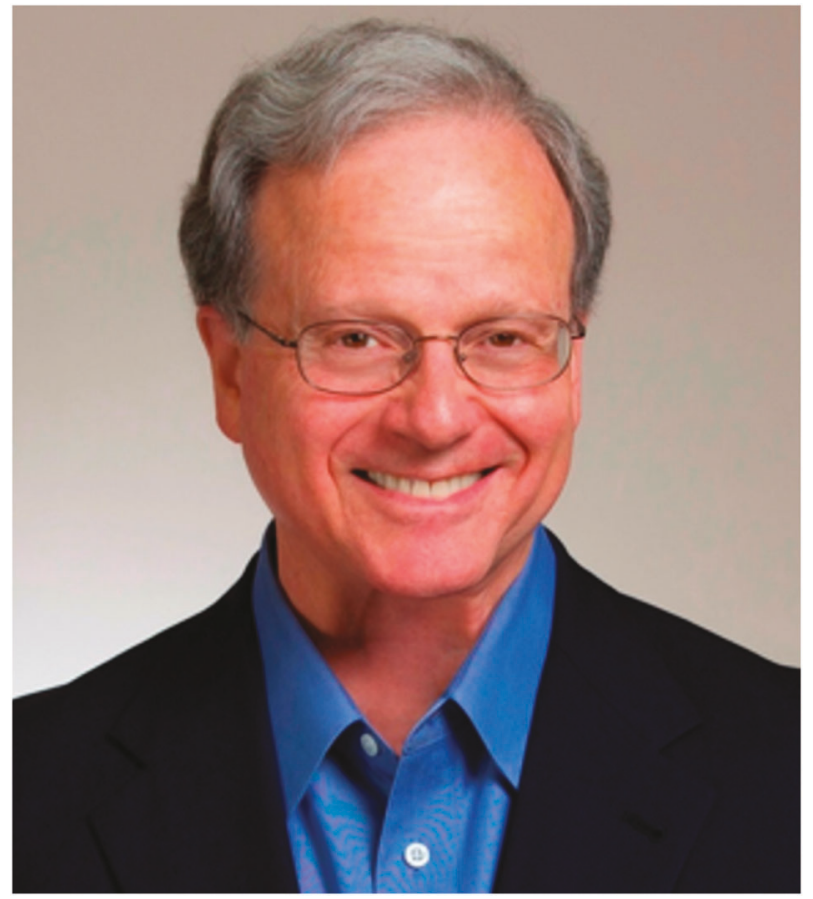

When Prof. Hal Broxmeyer boarded Pan Am flight 102 from New York to Paris in late September, 1988 accompanied by the family of a boy with Fanconi anaemia and lugging a $25 \mathrm{~kg}$ container with frozen human umbilical cord blood cells he was likely unaware of the huge future impact his trip would have on the lives of so many people. They were met at CDG by Prof. Elaine Gluckman who together with Hal did the 1st UCB transplant in 6 October of that year. The child is now an adult and as they say: The rest is history. We are now more than 40,000 UCB transplants later. Hal had to buy an extra seat for the container he called Big Boy and proudly exhibited in his office years later. His chances of getting past TSA today are less than zero and he might have ended up in Guantanamo rather than Paris.
Hal died on December 8th' just 3 days before the 63rd Annual Meeting of the American Society of Hematology for which he served as President, 2009-2010. We have lost a important contributor to experimental hematology whose research laid the groundwork for umbilical cord blood cell transplants. At scientific meetings he presented inspirational lectures and actively engaged in poster sessions, always friendly and smiling, participating in discussions, asking critical questions and commenting. Prof. Broxmeyer published 838 articles and edited several textbooks which are scientific roadmaps for younger colleagues. Hal was short and lithe. His scientific output when expressed on a square meter body surface area may qualify for the Guinness World Records. Importantly, he trained many outstanding investigators who will carry his memory forward.

Dr. Broxmeyer was born in Brooklyn, New York on 27 November 1944 before it was yuppie central. He grew up playing stickball (he could hit 2 sewers), going to Brooklyn Dodgers games and watching cowboy movies on weekends. He attended Brooklyn College where he focused on track and field, first running and later the javelin and shot put but his true athletic pursuit was weight-lifting, especially Olympic lifts. Prof. Broxmeyer competed in Masters Weightlifting competitions for many years winning the Masters National Championship in 1990 and 1994 in his age and weight divisions. Even after he stopped competitive weight-lifting he enjoyed a respite from science to exercise in his home basement where he kept serious weight-lifting equipment. He was also often seen in hotel gyms exercising before meeting sessions. MZR remembers on a trip to a Japan meeting Hal entered the aircraft schlepping a very heavy carry-on. MZR he tried to help Hal lift his luggage into an overhead compartment. Hal smiled raising his bag with 1 hand. Fait accompli.

Dr. Broxmeyer received his Ph.D. from New York University in 1973, completed a post-doctoral fellowship at Queens University, Kingston, Ontario and subsequently worked at Sloan-Kettering Institute in New York. A sun and warm weather enthusiast he unsurprisingly moved to Indiana University in Indianapolis in 1983 where he became Scientific Director at the Walther Oncology Center. Prof. Broxmeyer was Distinguished Professor, Mary Margaret Walther Professor Emeritus, Professor of Microbiology and Immunology and Senior Advisor to the Director of the

\footnotetext{
${ }^{1}$ Univ. Louisville, Louisville, KY, USA. ${ }^{2}$ Univ. Paris, Hospital St. Louis, Paris, France. ${ }^{3}$ Haematology Research Centre, Department of Immunology and Inflammation, Imperial College London, London, UK. ${ }^{凶}$ email: robertpetergale@alumni.ucla.edu This article is co-published in the journals Bone Marrow Transplantation https://doi.org/10.1038/s41409-02201576-y and Leukemia https://doi.org/10.1038/s41375-021-01504-x.
}

Received: 18 December 2021 Revised: 21 December 2021 Accepted: 10 January 2022

Published online: 25 February 2022 
National Cancer Institute-Designated Indiana University Simon Comprehensive Cancer Center at Indiana University School of where he built a highly-regarded center for experimental hematology.

Dr. Broxmeyer received many awards and honors including the Karl Landsteiner Award of the American Society of Blood Banks (2002), E. Donnall Thomas Prize of the American Society of Hematology (2007), Donald Metcalf Award of the International Society of Hematology and Stem Cell Research (2011), President's Medal of Honor from Indiana University (2019), Lifetime Achievement Award from the Cord Blood Association (2019) and Gold Medal of the City of Paris (1993).

Prof. Broxmeyer's research centered on regulation of hematopoiesis in the context of cyto- and chemokines. He proved Extra Physiologic Oxygen Shock/Stress (EPHOSS) is detrimental to haematopoietic stem cells and that this could be mitigated by collecting and processing cells in hypoxic conditions or with cyclosporine under ambient conditions. He was also interested in mobilization, trafficking, homing, engraftment and expansion of haematopoietic stem cells. His research in these areas is highly cited.

Hal developed thyroid cancer and lost normal use of his speech post-operatively. He told RPG he continued to lecture using an electronic assist device. Many of us struggle to lecture in a large auditorium without a speech impairment. When I told him I thought this exceptional he said: What else is there to do but soldier on. One month before his death he told MZR: I am still working every day as luckily my mind is still at full capacity, but it is physically very hard as most of the time I do not feel well. That's bravery! A true son of Brooklyn he never cheered for another baseball team after the Dodgers left Brooklyn in 1957 for Los Angeles and never lost his Brooklyn accent despite living almost 40 years in Indiana. That's loyalty!
Hal Broxmeyer, by every measure an extraordinary scientist and personality, will be missed by his students, collaborators, colleagues, friends and researchers worldwide. As they say in Brooklyn, he was a mensch.

\section{ACKNOWLEDGEMENTS}

RPG acknowledges support from the National Institute of Health Research (NIHR) Biomedical Research Centre funding scheme.

\section{AUTHOR CONTRIBUTIONS}

The authors planned, developed and approved the typescript submission for publication.

\section{COMPETING INTERESTS}

RPG is a consultant to BeiGene Ltd., Fusion Pharma LLC, LaJolla NanoMedical Inc., Mingsight Parmaceuticals Inc. CStone Pharmaceuticals, NexImmune Inc. and Prolacta Bioscience; advisor to Antengene Biotech LLC, Medical Director, FFF Enterprises Inc.; partner, AZAC Inc.; Board of Directors, Russian Foundation for Cancer Research Support; and Scientific Advisory Board: StemRad Ltd.

\section{ADDITIONAL INFORMATION}

Correspondence and requests for materials should be addressed to Robert Peter Gale.

Reprints and permission information is available at http://www.nature.com/ reprints

Publisher's note Springer Nature remains neutral with regard to jurisdictional claims in published maps and institutional affiliations. 